\title{
Certain Characteristics of Unlicensed Tree Expert Companies Advertising in Maryland, U.S.
}

\author{
Michael F. Galvin
}

\begin{abstract}
In 2005, Maryland's tree expert licensing law, initially enacted in 1945, was amended to include tree removal as an activity requiring a tree expert license. The Maryland Department of Natural Resources (MD DNR) sought to identify and communicate with the potentially affected community regarding the pending changes in the law by a number of means, including a search of companies advertising tree services in Maryland by online phone listings. The majority of firms $(69.91 \%)$ found to be advertising tree services online were unlicensed tree experts (UnLTEs). A significant number of those UnLTEs (40\%) did not provide full contact information, including a street address, and no current address was available for over $25 \%$ of them. Only 21 of the UnLTEs studied had ever been the subject of a complaint to MD DNR and those firms accounted for only $18.2 \%$ of complaints MD DNR received regarding UnLTEs during a 10 year period. UnLTEs were found in approximately equal measure in one of three business types: incorporated, unincorporated, or unknown (sole proprietorships, general partnerships, or noncompliant). UnLTEs are fairly ubiquitous in small numbers across Maryland with the largest concentrations found close to the borders of adjacent states, in the northeast metropolitan area of Maryland's largest city (Baltimore), and around the state capital (Annapolis).
\end{abstract}

Key Words. Arborists' licensing; commercial arborists; tree experts.

\section{DEFINITIONS}

NOTE: All definitions refer to the period of time following the passage of House Bill 168 (explained subsequently).

Licensed tree expert: a person who has received a license displaying the person's qualifications to practice as a tree expert (State of Maryland 2005).

Person: an individual, receiver, trustee, guardian, personal representative, fiduciary, representative of any kind, partnership, firm, association, corporation, or other entity (State of Maryland 1995).

Tree expert: a person who represents to the public that the person is skilled in the science of tree care or removal and who, whether in the business of the person or as the employee of another person and whether under the title of arborist, tree specialist, tree surgeon, tree expert, or otherwise, engages in the business or work of the treatment, care, or removal of trees for compensation by

1. Making diagnoses, prescribing, and supervising the treatment for trees; or

2. Trimming, pruning, thinning, cabling, shaping, removing, or reducing the crown of trees.

"Tree expert" does not include

1. A person engaged in commercial logging or timber harvesting operations;
2. A person engaged in the installation of underground facilities or any associated site construction; or

3. A person who treats, cares for, or removes a tree that is $20 \mathrm{ft}$ tall or less (State of Maryland 2005).

Unlicensed tree expert: a person who is a tree expert but is not a licensed tree expert.

\section{BACKGROUND}

On 5 April 1945, the Maryland General Assembly passed House Bill 61. This bill, the initial iteration of the Maryland Tree Expert law, required that persons performing tree care for hire be licensed by the State Forester. There are currently 671 licensed tree experts (LTEs) in Maryland. Tree care has historically been viewed by the state's legislature and courts as not including tree removal.

In recent years, numerous bills have been introduced in various legislative sessions with the intent of modifying the definition of the work of a tree expert (TE) to include tree removal. Most of these have been introduced at the request of, or been supported by, LTEs. In a survey of LTEs, Galvin and Becker (1998) reported that one of the primary programmatic modifications recommended by LTEs was revision of the LTE law to include tree removal in the definition of tree 
care. Such a modification would require persons performing tree removal for hire to meet the requirements of TE licensing, including qualification, examination, licensing, and proof of insurance.

The reasons for seeking inclusion of tree removal in the work of a TE included the following:

1. The American National Standard for safe work practices in the tree care industry includes "removing trees" in the scope of activities performed by arborists or tree experts (American National Standards Institute 2000);

2. Tree removal is often the most dangerous and expensive of tree care services. Ball and Vosberg (2003) reported that "Very few industries have a fatality rate above 30 per $100,000 \ldots$ the fatality rate among police officers and detectives is about 13.5 per 100,000 . . the annual fatality rate for tree workers generally does not dip below 30 per 100,000 and may be higher in some years." To then have tree removal be the only tree service not requiring licensing or insurance is counterintuitive;

3. LTEs were subject to sanction (suspension or revocation of license) if found guilty of negligence or wrongful conduct in the practice of tree culture or care during tree removal, but unlicensed tree experts (UnLTEs) did not need a license to remove trees and had no obligation with regard to standards of practice when performing removals; and,

4. Enforcement was very difficult under the existing language because practitioners performing tree care without a license often asserted in court that they were performing tree removal rather than tree care or that they charged for removals but performed pruning and other tree care for free to removal customers, thereby making those activities exempt from the law.

House Bill 168 (Moe and Frush 2005) sought to expand the definition of the work of a TE to include tree removal or various means of treating the crowns of trees. The bill provided exemptions for commercial logging or timber harvesting, installation of underground utility facilities or associated site construction, and for any activity performed on trees that are $6 \mathrm{~m}(19.8 \mathrm{ft})$ or less in height.

The latter unusual exemption was a compromise between legislators and the landscape industry. Landscapers sought an exemption from the law, but "landscapers" are undefined in Maryland law and so could not be exempted by name. Moreover, the law applies to certain types of activities rather than to certain types of businesses. That is, the law is applicable to any entity performing tree care for hire whether they are a tree service, a landscaper, a home improvement contractor, or other type of business. The phrase "trees that are 20 feet or less in height" was derived from certain horticultural definitions of a tree being a woody plant that attains a height of at least $6 \mathrm{~m}(19.8 \mathrm{ft})$ at maturity (State of Maryland 2003).

This legislative action showed how the tree care industry can be proactive in partnering with government to arrive at a solution rather than be a nonparticipant on the receiving end of a legislative action that had no industry involvement or consideration.

The law requires that prospective licensees meet the qualifications for licensure, including passage of an examination administered by the Maryland Department of Natural Resources (MD DNR), and maintenance of insurance protection (liability and workers' compensation) for the period that the license is in effect.

Enforcement mechanisms vary depending on whether the offender is an LTE or an UnLTE. If the offender is an LTE, penalties apply for: fraud or deceit in obtaining the license, negligence or wrongful conduct in the practice of tree culture or care, or violation of rules of ethics that the department promulgates (State of Maryland 2005). Penalties for LTEs are administrative; the only penalty available under law is suspension or revocation of the LTE's license. If there is no settlement or remediation, and if the agency finds cause to proceed with an action against the LTE's license, such cases are ultimately ruled on by an independent third party, an administrative law judge at Maryland's Office of Administrative Hearings. If the offender is an UnLTE, penalties apply for operating a tree expert business without a license or false advertising or soliciting an unlicensed tree expert business (District Court of Maryland 2003). These charges are misdemeanor criminal citations handled by the District Court system.

House Bill 168 passed and was effective 1 October 2005. Because many UnLTEs who would not be subject to penalty before passage of House Bill 168 could be subject penalty after the effective date of the legislation, MD DNR sought to identify and communicate with UnLTEs regarding the pending changes in the law in an effort to facilitate compliance. This was difficult because there was no registry of, or trade association for, UnLTEs. MD DNR ultimately mailed notice to over 1,400 UnLTEs identified by various means.

This article relates to one component of this outreach effort: identification of and outreach to UnLTEs advertising tree care services through online phone listings. We sought to answer the following questions related to these UnLTEs:

1. How many UnLTEs are there advertising by this means, and how does this compare with the number of LTEs advertising in the same manner?

2. What types of contact information do these UnLTEs include in their advertising?

3. How many of these UnLTEs have previously been the subject of complaints to MD DNR regarding the LTE law? 
4. How many of these UnLTEs have Maryland Department of Assessments and Taxation (SDAT) Business Entity Registrations (BERs) and, if so, what type?

5. What response, if any, was received related to the notification mailed to these UnLTEs?

6. What is the spatial distribution of these UnLTEs?

This particular subset was differentiated from the rest of the group for the following reasons:

1. MD DNR had complete contact information for all other records in the listing of over 1,400 UnLTEs because they possessed some other state-issued license, registration, or credential that required provision of full contact information; and

2. Because false advertising or soliciting an unlicensed tree expert business without a license is a criminal offense, this subset contained a listing of highly probable knowing or unknowing violators on the effective date of the change in law.

\section{METHODS}

We searched online directories of Verizon and AT\&T telephone listings for tree services and related businesses by using the business type query. The following business categories were searched: arborists, ornamental tree and shrub service, tree consultants, tree services commercial and industrial, tree and shrub spraying, tree and stump removal services, and tree trimming services. Results were transposed into an Excel spreadsheet with one worksheet per business category. All entries were appended to a master worksheet and sorted alphabetically by company name. Redundancies were eliminated.

Spreadsheet fields were added to denote: tree expert licensing status; whether the company had ever been the subject of a tree expert complaint; whether the company in question had an SDAT BER, and if so, the BER name; the BER status; the SDAT account number; the description of the business according to the BER filing; company contact information; the date notification of the law change was mailed to the particular company; and what the response was, if any, to the mailing.

Information on licensing status and complaint status was obtained from MD DNR databases. BER information was obtained from the SDAT Web site.

Information from the ZIP code field of the contact information from the spreadsheet was tallied and associated with a zip code GIS shapefile in ArcView. The data were classified by natural breaks in the data into three categories. The results were projected spatially in a GIS map.

\section{RESULTS AND DISCUSSION}

After eliminating redundant entries found in multiple business category listings, the total number of entries was reduced
Table 1. Comparison of LTES and UnLTEs advertising online.

\begin{tabular}{lcl}
\hline Tree expert (TE) type & $\begin{array}{l}\text { No. } \\
\text { of TEs }\end{array}$ & $\begin{array}{l}\text { Percentage } \\
\text { of TEs }\end{array}$ \\
\hline Licensed (LTE) & 68 & 30.09 \\
Unlicensed (UnLTE) & 158 & 69.91 \\
Total & 226 & \\
\hline
\end{tabular}

from over 1,000 to 226. A comparison of the TE license status of the 226 companies advertising tree services in the online directories of Verizon and AT\&T telephone listings is found in Table 1.

LTEs are required to file contact and insurance information annually to renew the license and are required by regulation to "... within a reasonable time, inform the Department of Natural Resources Forest Service in writing of a change in address, telephone number, or employment" (State of Maryland 2002). Lack of complete contact information can result in the following negative impacts for TEs, clients of TE services, and regulators:

1. Limitation of customer communication in the event of a complaint;

2. Reduction of the TE's ability to be found by a prospective customer; and,

3. Limitation of a regulator's ability to advise of regulatory changes that may affect the TE.

However, many of the UnLTEs identified had incomplete contact information (Table 2) despite our consultation with multiple sources (online phone listings, SDAT BER, MD DNR complaint database) to obtain it. We found no, or incomplete, contact information for $42(26.5 \%)$ UnLTEs. According to the MD DNR, unlicensed tree experts “... will often give a cell phone number and no other means of contact, thereby making it difficult to find them should a problem arise" (Maryland Department of Natural Resources 2005).

Two recipients responded in writing to assert that the provisions of House Bill 168 were not applicable to them. One

\section{Table 2. Availability of various types of contact information for unlicensed tree experts (UnLTEs) advertising online.}

\begin{tabular}{lll}
\hline $\begin{array}{l}\text { Availability of contact info } \\
\text { for UnLTEs }\end{array}$ & $\begin{array}{l}\text { No. of } \\
\text { UnLTEs }\end{array}$ & $\begin{array}{l}\text { Percentage of } \\
\text { UnLTEs }\end{array}$ \\
\hline Provided city, state, and ZIP code & 152 & 96.20 \\
Provided street address & 95 & 60.13 \\
Provided a web site address & 48 & 30.38 \\
Provided an e-mail address & 32 & 20.25 \\
$\begin{array}{l}\text { Returned by US postal service as } \\
\quad \text { undeliverable }\end{array}$ & 31 & 19.62 \\
Insufficient information for mailing & 11 & 6.96 \\
\hline
\end{tabular}


Table 3. Tally of all tree complaints, 1995 to 2005, by licensing status.

\begin{tabular}{lll}
\hline Licensed tree expert type & $\begin{array}{l}\text { No. of } \\
\text { complaints }\end{array}$ & $\begin{array}{l}\text { Percentage } \\
\text { guilty }\end{array}$ \\
\hline Licensed tree expert & 181 & 47 \\
Unlicensed tree expert & 274 & 49 \\
Total & 455 & 96 \\
\hline
\end{tabular}

advised MD DNR that they had hired a licensee and were now in compliance and provided proof of the same. Another wrote: "We do not have any licensed tree experts on staff, nor do we advertise this type of service ... the nature of our business is strictly that of a land clearing and grubbing contractor" (Blum 2005, pers. comm.). This was submitted despite the fact that according to their SuperPages.com business profile, their products and services are listed as "tree and root surgery" and their business name includes the phrase "... Tree Service."

For the period between state fiscal year (FY) 1995 and FY 2005, MD DNR received hundreds of complaints against TEs with findings of guilt against LTEs and UnLTEs in approximately equal number (see Table 3). Only 21 (13\%) of the UnLTEs identified had ever been the subject of a complaint to the MD DNR regarding violation of the Tree Expert Law (Table 4); however, those same 21 UnLTEs had been the subject of 50 complaints for violating the TE law. One of the persons listed as being charged with an offense reserved for LTEs (negligence or wrongful conduct on the practice of tree care) was licensed at the time of that allegation but was no longer licensed at the time of this study. A small number of UnLTEs were alleged to be operating without a license on single occasions, whereas those charged with false advertising were, on average, two-time offenders. Those UnLTEs charged with both offenses appear, on average, to be offenders at a ratio of over $3: 1$, but in fact, a small number are responsible for most of the recidivism (one UnLTE was the subject of 13 different complaints [26\% of the 50 complaints] involving one or both charges. This UnLTE recently became an LTE for the first time).

Corporations, limited liability companies, and limited partnerships are required to file a BER with the State Department of Assessments and Taxation. Sole proprietorships and general partnerships are not required to file a BER but may file if they want to register a trade name ("doing business as" [DBA]).

The types of registered business entity status and their definitions are listed in Table 5. Slightly more than half ( 88 [56\%]) of unlicensed firms advertising had BERs. Seventy firms (44.30\%) had no BER. Among firms having a BER, BER status was almost equally divided between incorporated (40\%) and unincorporated (39\%) firms. Fifteen percent of firms with a BER were in forfeited status resulting from noncompliance.

Although Maryland's population is concentrated in the Baltimore-Washington corridor, UnLTEs are fairly ubiquitous in small numbers across the state (Figure 1). The largest concentrations were found close to the borders of adjacent states that do not require TE licensing, in the northeast metropolitan area of Maryland's largest city (Baltimore), and around the state capital (Annapolis).

\section{CONCLUSIONS}

Although Maryland has had TE licensing for 60 years, the majority of TEs $(69.91 \%)$ advertising in online telephone listings are UnLTEs. A significant number of those UnLTEs $(40 \%)$ did not provide full contact information, including a street address, and we could not find a current address for over $25 \%$ of them. One of the two criminal charges possible under the Tree Expert Law is "false advertising or soliciting an unlicensed tree expert business" (District Court of Maryland 2003), and this study related specifically to TEs advertising their services. Still, the UnLTEs studied accounted for only $18.2 \%$ of complaints MD DNR received regarding UnLTEs during a 10 year period.

UnLTEs were found in approximately equal measure in one of three categories: incorporated, unincorporated, or unknown (sole proprietorships, general partnerships, or noncompliant).

UnLTEs are common in small numbers across the state with concentrations near the borders of adjacent states that do not require arborists' licensing and in and around the primary urban areas.

Table 4. Summary of complaints against unlicensed tree experts advertising online by offense type.

\begin{tabular}{|c|c|c|}
\hline Charge & $\begin{array}{l}\text { No. of } \\
\text { tree experts }\end{array}$ & $\begin{array}{l}\text { Total no. } \\
\text { of charges }\end{array}$ \\
\hline Operating a tree expert business without a license & 4 & 4 \\
\hline Negligence or wrongful conduct on the practice of tree care & 1 & 1 \\
\hline False advertising or soliciting an unlicensed tree expert business & 5 & 10 \\
\hline $\begin{array}{l}\text { Operating a tree expert business without a license AND false adv } \\
\text { tree expert business }\end{array}$ & 11 & 35 \\
\hline Total & 21 & 50 \\
\hline
\end{tabular}


Table 5. Business Entity Registration (BER) type for unlicensed tree experts advertising online.

\begin{tabular}{|c|c|c|c|}
\hline BER status & Definition & $\begin{array}{l}\text { No. of } \\
\text { firms }\end{array}$ & $\begin{array}{l}\text { Percentage } \\
\text { of firms }\end{array}$ \\
\hline No BER & Not applicable & 70 & 44.30 \\
\hline Incorporated & This corporation is legally active and present in Maryland. & 35 & 22.15 \\
\hline Active & This unincorporated entity is legally active and present in Maryland. & 34 & 21.52 \\
\hline Forfeited & $\begin{array}{l}\text { For a Maryland entity, its existence has been ended by the state for some delinquency. For a } \\
\text { non-Maryland entity, it means its authority to do business and legal presence here has been } \\
\text { terminated. For a trade name, it means the filing has lapsed after } 5 \text { years and not been renewed. }\end{array}$ & 13 & 8.23 \\
\hline Inactive & Not active & 4 & 2.53 \\
\hline Revived & $\begin{array}{l}\text { The entity is currently back to active status after having been forfeited in the past. The entity took } \\
\text { the legal steps necessary to reinstate its existence. }\end{array}$ & 2 & 1.27 \\
\hline Other & Canceled, consolidated, dissolved, merged, old name & 0 & 0 \\
\hline
\end{tabular}

\section{RECOMMENDATIONS}

To facilitate communication with existing clients, increase business opportunities with prospective clients, stay in compliance with regulators, and to remain abreast of regulatory changes, TEs should provide full contact information, including a physical address for the business.

The change in the Tree Expert Law brought about by the passage of House Bill 168 should clarify the rules of practice, provide consumer protection, and ensure that TEs are properly insured. This latter point will provide protection for tree service workers as well as "level the playing field" for LTEs that at times have to fight being underbid by firms that can operate more cheaply because they have inadequate or no insurance and therefore less overhead. Although passage of this bill should facilitate improved enforcement by the MD DNR, the lack of a grandfathering provision in House Bill

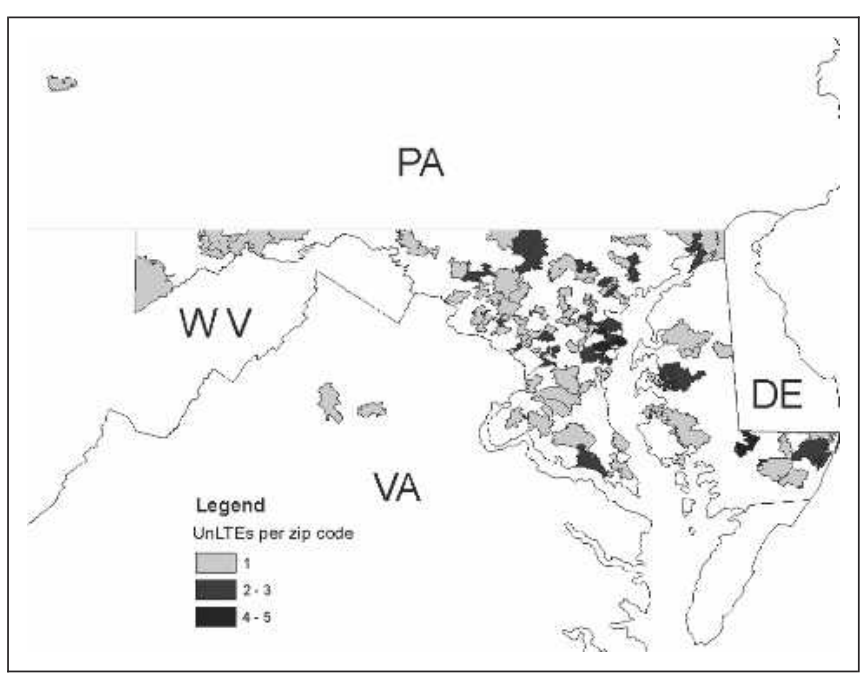

Figure 1. Map of zip codes in Maryland and surrounding jurisdictions, classified by the number of unlicensed tree experts advertising online and using a particular zip code in their address of record.
168 left many firms with compliance issues resulting from the existing qualifications for licensure (2 years related college course work and 1 year under a licensee, or, for at least 5 years immediately before the date of application, to have been engaged continuously in practice as a tree expert with a licensed tree expert in Maryland or with an acceptable tree expert company in another state). UnLTEs would have to hire someone possessing a license, hire someone that qualifies to obtain a license, or find an LTE willing to allow the UnLTE to work under their license to be in compliance. The costs associated with such arrangements are prohibitive to many UnLTEs, and the risks associated with such arrangements are prohibitive to many LTEs. MD DNR has been working with elected officials, LTEs, and UnLTEs to reach an equitable resolution and hopes that such a remedy will be passed when the General Assembly next convenes.

Acknowledgments. The author thanks Maryland's tree care industry, including the Maryland Arborist Association, the Tree Care Industry Association, the Mid-Atlantic Chapter of the International Society of Arboriculture, the Association of Forest Conservancy District Boards/Maryland Urban and Community Forest Committee, and the Maryland Electric Reliability Tree Trimming Council for their partnership in Maryland's Tree Expert licensing program.

\section{LITERATURE CITED}

American National Standards Institute (ANSI). 2000. American National Standard for Arboricultural OperationsPruning, Repairing, Maintaining, and Removing Trees, and Cutting Brush—Safety Requirements, ANSI Z133.1—2000. American National Standards Institute, New York, NY.

Ball, J., and S. Vosberg. 2003. How accidents happen and why: Arboricultural safety in the US. Tree Care Industry $14: 50-54$.

District Court of Maryland. 2003. DCAR XVIII. Natural Resources Fine Schedule. Administrative Office of the Courts. Annapolis, MD.

Galvin, M.F., and P. Becker. 1998. A survey of licensed tree experts in Maryland. Journal of Arboriculture 24:35-41. 
Maryland Department of Natural Resources. 2005. DNR offers Marylanders tips on choosing a licensed tree expert: Recent law alters definition of tree expert to include tree removal. www.dnr.state.md.us/dnrnews/pressrelease2005/ 052405.html (accessed 9/13/05).

Moe, B.R., and B. Frush. 2005. House Bill 168. Maryland General Assembly. http://mlis.state.md.us/2005rs/billfile/ hb0168.htm (accessed 12/8/05).

State of Maryland. 2002. Code of Maryland Regulations. Title 08, Subtitle 07, Chapter 07. http://www.dsd.state. md.us/comar/08/08.07.07.01.htm (accessed 9/13/05).

- 1995. Annotated Code of Maryland, Business Regulation Article. Title 1, Subtitle 1. http://198.187.128.12/ maryland/lpext.dll? $\mathrm{f}=$ templates $\& \mathrm{fn}=\mathrm{fs}-\mathrm{main} \cdot \mathrm{htm} \& 2.0$ (accessed 12/7/05).

- 2003. Annotated Code of Maryland, Natural Resources Article. Title 5, Subtitle 16. Office of the Secretary of State, Division of State Documents. Annapolis, MD. 24 pp.

- 2005. Annotated Code of Maryland, Natural Resources Article. Title 5, Subtitle 4. www.dnr.state.md.us/ download/telaw.pdf (accessed 12/7/05).

\author{
Michael F. Galvin \\ Supervisor \\ Urban \& Community Forestry, Maryland Forest Service \\ Maryland Department of Natural Resources \\ 580 Taylor Avenue \\ Annapolis, MD 21401, U.S. \\ mgalvin@dnr.state.md.us
}

Résumé. En 2005, la Loi sur la licence d'experts en arbres du Maryland, initialement adoptée en 1945, a été amendée pour inclure l'abattage des arbres parmi les activités requérant un expert licencié. Le Département des ressources naturelles du Maryland (DRN MD) a cherché à identifier et à communiquer avec la communauté potentiellement affectée en regard des changements en cours avec la loi, et ce par plusieurs moyens incluant une recherche des compagnies qui annonçaient des services en arboriculture via les listes téléphoniques. La majorité des entreprises $(69,91 \%)$ dont on a découvert qu'elles annonçaient des services en arboriculture n'étaient pas des experts en arbres licenciés. Un nombre significatif de ces non licenciés $(40 \%)$ ne fournissaient pas de coordonnées complètes de leur adresse et aucune adresse n'était disponible pour 25\%. Seulement 21 des entreprises non licenciées étudiées ont déjà été l'objet d'une plainte par le passé auprès du DRN MD et ces firmes comptaient pour seulement $18,2 \%$ des plaintes reçues au DRN MD en regard d'entreprises non licenciées durant une période de 10 ans. Les firmes non licenciées se répartissaient également parmi trois types d'entreprises: incorporées, enregistrées (non incorporées) ou non définies (travailleur autonome, associé, illégal). Les firmes non licenciées sont plutôt omniprésentes en faibles nombres dans l'ensemble du Maryland avec un nombre plus important à proximité des frontières avec d'autres états, dans le nord-est de la zone métropolitaine de la plus grande ville de l'état (Baltimore) et autour de la capitale de l'état (Annapolis).

Zusammenfassung. 2005 wurde das aus dem Jahr 1945 stammende Gesetz zur Lizenzierung von Baumexperten dahingehend geändert, dass die Entfernung/Fällung von Bäumen eine lizenzpflichtige Leistung wird. Das Amt für Natürliche Ressourcen in Maryland hatte dabei das Anliegen, potentiell gefährdete Kommunen zu erkennen und darüber zu kommunizieren, wie die Gesetzesänderungen umzusetzen sind, inklusive der Auswahl der Firma aus dem Angebot der online gelisteten Baumservice-Firmen. Die Mehrheit der inserierenden Firmen $(69,91 \%)$ hatte keine Lizenz. Eine große Zahl der unlizenzierten Firmen (40\%) lieferten nicht die vollen Kontaktangaben inkl. einer Anschrift und bei über $25 \%$ war keine gegenwärtige Adresse erhältlich. Nur $21 \%$ dieser Firmen waren je Grund einer Beschwerde beim Amt für Natürliche Ressourcen und diese Firmen verursachten nur 18,2 \% alle Beschwerden über eine Zeitraum von 10 Jahren. Unlizenzierte Firmen wurden in etwa gleichem Ausmaß in einer von drei Geschäftstypen gefunden: als AG, nicht-AG oder unbekannt (Alleinunternehmer, Partnerschaften oder nicht konform). Unlizenzierte Firmen sind in kleinen Zahlen überall in Maryland vertreten. Die größte Konzentration wird an den Grenzen zu den benachbarten Bundesstaaten gefunden, im Großraum von Baltimore im Nordwesten und um die Bundeshauptstadt Annapolis.

Resumen. En el 2005, la ley de expertos en árboles de Maryland, presentada inicialmente en 1945, fue enmendada para incluir la remoción de árboles como una actividad que requería una licencia. El Departamento de Recursos Naturales de Maryland (MD DNR, por sus siglas en inglés) pensó identificar y comunicar con las comunidades potencialmente afectadas, en relación a los cambios en la ley, por un número de medios, incluyendo una búsqueda de anuncios de compañías de servicios de árboles en Maryland, vía las listas telefónicas en Internet. Se encontró que la mayoría de firmas (69.91\%) contenían en sus anuncios Expertos Arboristas no licenciados (UnLTEs, por sus siglas en inglés). Un número significativo de estos UnLTEs (40\%) no proporcionaron información completa de contacto, incluyendo dirección, y el $25 \%$ de ellos no tenían dirección actualizada disponible. Solamente 21 de los UnLTEs estudiados habían sido sujetos de una queja al MD DNR y estas firmas respondieron por solamente $18.2 \%$ de las quejas al MD DNR recibidas en relación a los UnLTEs durante un período de 10 años. Estos UnLTEs fueron encontrados aproximadamente en igual medida en uno de los tres tipos de negocios: incorporados, no incorporados o desconocidos (solo el propietario, comercio en general, o sin quejas reportadas). Los UnLTEs son negocios pequeños difíciles de ubicar, con las concentraciones más grandes cerca de las fronteras adyacentes a los estados, en el noreste del área metropolitana de la ciudad más grande de Maryland (Baltimore), y alrededor de la capital del estado (Annapolis). 